Volume 9, No.1, January - February 2020

International Journal of Advanced Trends in Computer Science and Engineering

Available Online at http://www.warse.org/IJATCSE/static/pdf/file/ijatcse65912020.pdf

https://doi.org/10.30534/ijatcse/2020/65912020

\title{
Gamification for Better Patient Experience in Queue at the Hospital
}

\author{
Gunawan Wang ${ }^{1}$, Hans Kristian ${ }^{2}$, Paul Weniko ${ }^{3}$ \\ Information Systems Management Department, BINUS Graduate Program - Master of Information Systems \\ Bina Nusantara University, Jakarta, Indonesia, 11480 \\ 1'gwang@binus.edu; ${ }^{2}$ hans.kristian001@binus.ac.id; ${ }^{3}$ yweniko@binus.edu
}

\begin{abstract}
Everyone who wants to visit the hospital always expects to get proper service facilities and is not interrupted by waiting times or queuing in line for too long. Likewise with a service system, the hospital should try to provide the best service facilities. This research presents a framework of gamification that is applied to the game elements integration. With this gamified system patients are expected to be able to play games while waiting for their examination turn without feeling boring. Another expectation of using the gamified system is to see the loyalty of patients who frequently visit the hospital. This includes architecture for gamified systems and guidelines to assist in the gamified activities development.
\end{abstract}

Key words : Hospital, Queuing, Gamification, Gamified System, Architecture

\section{INTRODUCTION}

Waiting is very boring for many people because it will only waste a lot of their time. Especially if waiting is experienced by people who need immediate service. This waiting situation often occurs in a queue, for example a plane that will land or take off, an engine that will be repaired, customers who conduct transactions at the bank and patients waiting for their doctors. Queues occur when customers who come to a service exceeds available service capacity. Customers come to that place with random time, irregular and cannot be served immediately so they have to wait long enough (Kakiay, 2004) [1]. To provide customer satisfaction, a system must try to provide the best service. The best service that is intended is to provide facilities that make customers become unsaturated in waiting. In overcoming problems related to the queue, one means that can be made is to use the concept of Gamification with the intention to make the impression of waiting is not boring if accompanied by a game play. Queuing in real life is very often found in hospitals as interpreted as patients waiting for their doctors to be examined, the situation while waiting causes discomfort for patients. If this is not immediately addressed, it will become a serious problem for the hospital because it can affect the confidence of the patient himself. According to Parameswaran [2], ineffective queues can result in dissatisfaction with customers. Given the importance of queues, it is possible to note the need not only to monitor queues individually but to understand the motives that made these queues occur.

\section{RELATED WORK}

\section{A. Queuing Theory}

Queuing Theory is a waiting line from a person who need services from the existing system [3]. An organization needs to make a good facility or service so that their customers don't get bored waiting. In addition, fast service will retain customers in the long run to increase the profitability of their organization. A queue system is a set of customers, waiters and a queue that regulates the arrival of customers and processing the problem. Customers who arrive may be permanent or non-permanent to obtain service. If a customer who arrives can directly enter the service system, the customer is immediately served, conversely if they have to wait then they have to form a queue until it is time the customer is given service [4].

\section{B. Queuing System}

Queue system is the arrival of customers to get service. In general, the arrival of customers is not known beforehand, because if it can be known then the operation of the facility can be scheduled in such a way that it will completely eliminate the need to wait. There is a scheme where if the queue is too long it can be called balking [5]. Customers who are impatient and decide to leave the system before serving are called reneging [6].

\section{Gamification}

Gamification is a concept in which players perform certain activities and rules to achieve a goal and the existence of rewards when successfully achieving it (Huotari \& Hamari, 2012) [7]. In its implementation it is made as if someone were playing a game. By giving awards or certain parameters that can make them feel like playing a game. With gamification will be able to make someone feel excited to continue to use the application. Summed up by a book by Scot Haris and Kevin O'Gorman (2014: 37-84) [8] the elements in gamification are: 
1. Determine the player. The intended players are consumers.

2. Make a fun plan on a website display system or application designed with great fun.

3. Motivate players. Motivate players to continue to follow gamification by giving rewards, points, ranks and leaderboard.

\section{RESEARCH METHOD}

This study proposes a framework for system software, namely gamified applications. Stevens and Pooley (2000) find that gamification framework is an architecture that is suitable for gamified systems, along with general functions. [9]. Concepts that support the framework and a general description of the elements of the game. In addition to these structures, the elements and architecture used must be considered, and how they contribute to their objectives. The architecture used in the gamification process must allow the system to produce good gamification. Architecture shows an activity that is becoming gamified system structure, which should be the key ingredient that is considered and why they are related to one another.

\subsection{Core Concept}

Zichermann (2011) [10] identified three recurring construct in a gamified system: Feedback, Friends, and Fun. Feedback is a signal or response that contains the impression of the recipient of the message in verbal and nonverbal form. This intended to maintaining a professionalism of entanglement. Friends relate to social contexts, a place for collaboration and sharing social game features. Fun act for the innate component of entertainment and gladness found in the games. In the advanced framework, these three elements are supplemented by the notion of Csikszentmihalyi (1990) [11]. The final step of this gamified system is the experience of its users and leaving their positive impression. Flow \& fun must include in the design of cross-sectional systems that are associated with other components.

\subsection{Game Elements}

Every game has "elements" or features that keep people engaged. Some games have a lot; others have very few. The choice of what to include should be deliberate. With learning games, you should consider how each element supports the learning process. In this research, the elements of the game are linked to the core concepts beforehand (Table 1). Feedback can be realized through rewards such as story, level, and rewards.
Table 1: Core Concepts and Game Elements

\begin{tabular}{|c|l|l|}
\hline \multicolumn{2}{|l|}{ Core Concept } & Game Elements \\
\hline \multirow{2}{*}{} & $\begin{array}{l}\text { Feedback \& } \\
\text { Rewards }\end{array}$ & $\begin{array}{l}\text { Points, progress bars, badges, trophies, } \\
\text { leaderboards }\end{array}$ \\
\cline { 2 - 3 } & Friends & $\begin{array}{l}\text { Sharing, inviting friends, give/trade/ask } \\
\text { for virtual goods, leaderboards (social } \\
\text { graph) }\end{array}$ \\
\cline { 3 - 4 } & & $\begin{array}{l}\text { Levels, intermediate goals, clear } \\
\text { objectives, fun failure, rules, rewards }\end{array}$ \\
\hline
\end{tabular}

The concept of gameplay including game dynamics represents the interaction of players with the game. The game elements must have clear objectives, intermediate objectives, levels or related rewards in this gameplay concept. Rewards defines the frequency and conditions for their assignments. Fun failure is a process of repeating after a failure and an effort to make it fun, and also making the player feel controlled. Linder (2013) shows that mastery and progress are one component of personal experience that is easy to recognize. Progress can be interpreted as the implementation process through elements in feedback \& rewards. Players can be challenged by doing tasks that are considered too difficult and not too easy (Csíkszentmihályi 2000). The results are obtained from feedback on goals and various stages of development. In the way the challenges are balanced with the player skills.

\subsection{Architecture}

This architecture (Figure 1) is a three-level design for an architectural software with a level of user interface, system logic and data interface. At the data level, blocks are recognized as "Activity Manager" where players get information from external sources, while "Connection Manager" run links with outside applications. For instance, the results are to be published the accomplishment of the players on social networks.

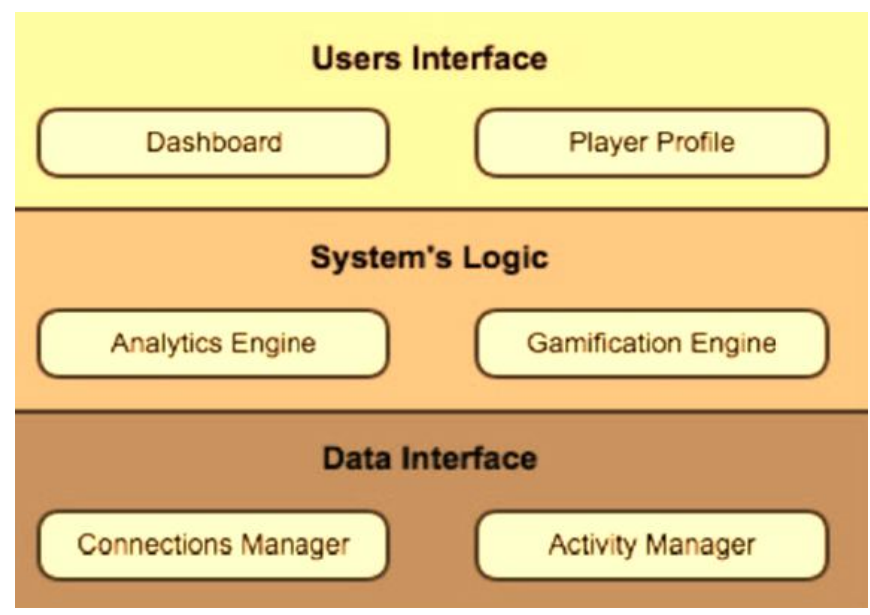

Figure 1: A Theree-tier Model of Gamification

\subsubsection{Dashboard}

Dashboard allows users to access non-players in the system. This user can be a system object and some type of system administrator. 


\subsubsection{Player Profile}

A players to determine the gamification. This player can set external application, that they want to share their data.

\subsubsection{Analytics Engine}

It creates tailored data solutions that enable to make decisions more effectively and efficiently. In addition there is an analysis which is an algorithm applied to proceeding several key for execution (Werbach \& Hunter, 2012) [12].

\subsubsection{Gamification Engine}

Provide that the application of gaming elements to activities that are not normally associated with the game

\subsubsection{Connection Manager}

Used to establish links with contexts which has nothing to do with the game. Gamified systems rely on external devices to track connection requirements on the device. This device need to be synchronized with website to collect the data

\subsubsection{Activity Manager}

Activity managers from the system can monitor and also get data from some kind of external sources, as well as other the players with their activities.

Table 2: Reference Guide to Apply Gamification

\begin{tabular}{|c|c|}
\hline $\begin{array}{l}\text { 1. Non-game } \\
\text { context } \\
\text { characterization }\end{array}$ & $\begin{array}{l}\text { 1.1. Context's nature: digital or non- } \\
\text { digital } \\
\text { 1.2. Identify target activities } \\
\text { 1.3. Identify target behaviors } \\
\text { 1.4. Players' profiles characterization }\end{array}$ \\
\hline $\begin{array}{l}\text { 2. Set the system's } \\
\text { objectives }\end{array}$ & $\begin{array}{l}\text { 2.1. Define the goals in relation to } \\
\text { the target behaviors } \\
\text { 2.2. Quantify the goals (KPIs) }\end{array}$ \\
\hline $\begin{array}{l}\text { 3. Select game } \\
\text { elements }\end{array}$ & $\begin{array}{l}\text { 3.1. Define the goals in relation to the } \\
\text { target behaviors } \\
\text { 3.2. Quantify the goals (KPIs) }\end{array}$ \\
\hline $\begin{array}{l}\text { 4. Select meaningful } \\
\text { data }\end{array}$ & $\begin{array}{l}\text { 4.1. Define the process to monitor } \\
\text { and collect data } \\
\text { 4.2. Define the actions to be } \\
\text { monitored } \\
\text { 4.3. Define the rules } \\
\text { 4.4. Data analysis regarding } \\
\text { systems' objectives ( } 2.2) \\
\text { 4.5. Select game elements for } \\
\text { feedback }\end{array}$ \\
\hline 5. Evaluate results & $\begin{array}{l}\text { 5.1. Compare results with the } \\
\text { objectives } \\
\text { 5.2. Optimize rules if needed }\end{array}$ \\
\hline
\end{tabular}

\section{APPLYING A GAMIFICATION FRAMEWORK}

The suggested framework was implemented on the platform as well as the majority of users to engage in the activities of the platform. At this point, gamification of this interface will encourage user involvement and loyalty in patients. The guidelines will help patients through the process by showing what games are suitable for their personal pleasure. This platform will furnish the tools needed to construct a predetermined game process, for example: allowing patients to personalize themselves and get badges, trophies, virtual items, or gifts.

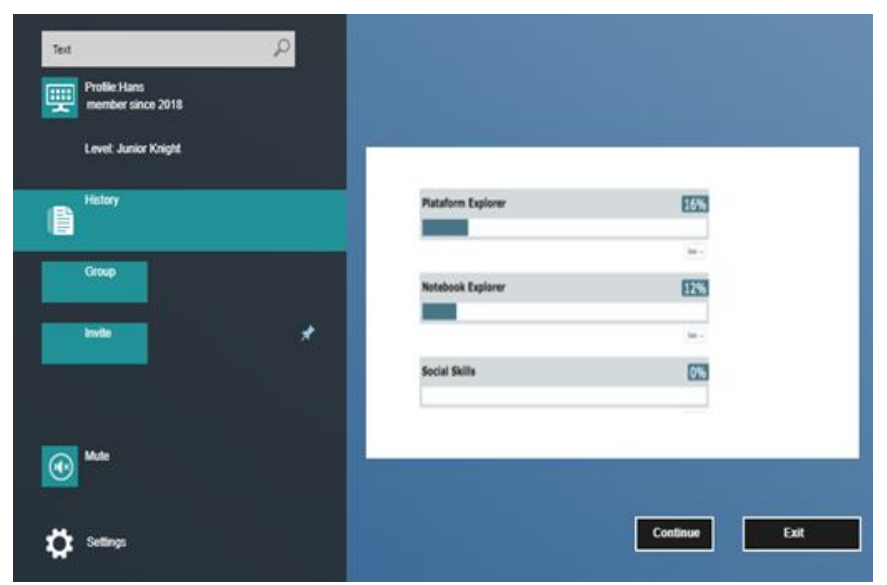

Figure 2: Achievements Interface

All player actions are monitored and recorded. Rules are set for each game chosen, players can get their achievements by getting rewards. Users who have just joined for the first time will receive a badge. In the player interface, the points collected will automatically be displayed along with the best total points. The results of the achievements of users who have participated and have used the platform are divided into three categories (Figure 2).

\section{CONCLUSIONS AND FUTURE WORK}

Gamification is a platform which aims to motivate people to do something. Gamification must also have meaning and purpose. It must aim to grow intrinsic players and not just want to get motivated. All activities are designed to have quality and added value for players, such as if some features are removed from the system, then any remaining content does not degrade the quality of the game. In that interface there is a gamified system feature. From the proposed architecture it has machine gamification, analytics, and player connections. An activity manager tracks all the players' behavior according to the rules imposed in the gamification engine and from the managed system generates points that will be given to that player. In the end players can also see the points they have achieved with the categories displayed, besides that Social interaction between patients is achieved through social features platforms. The next step is to evaluate the platform that is Gamified into a scenario. 
In the future, it is hoped that through this gamification platform system that this system can be extended to the real world. The next step is that patients can also become players in the sense that they also need to be motivated and involved with the system. The proposed framework is a framework that aims to build a gamified system. This is an architecture to show you that in developing a gamified system a method can be applied which aims to make the use of gamified efficient and effective in hospitals to provide meaningful experiences. In the end, there is an impression from patients that in their queues, waiting is no longer boring for them.

\section{REFERENCES}

1. Kakiay, T. J. 2004. Dasar Teori Antrian Untuk Kehidupan Nyata. Penerbit Andi. Yogyakarta

2. V. Parameswaran, V. Shet, and V. Ramesh. Design and validation of a system for people queue statistics estimation. Video Analytics for Business Intelligence, pages 355-373, 2012. https://doi.org/10.1007/978-3-642-28598-1_11

3. Sumarno M., Y. Langi., dan L. Latumakulita. 2015. Model Antrian pada Sistem Pembayaran di Golden Pasar Swalayan Manado. Jurnal de Cartesian. 4(2) : 180-187.

https://doi.org/10.35799/dc.4.2.2015.9057

4. Hilier L. 2008. Introduction to Operations Research, jilid 2. Penerbit Andi. Yogyakarta.

5. Dimyati. 1999. Sistem Antrian. Jakarta

6. Mulyono, S. 2007. Rist Operasi Lembaga Penerbit Fakultas Ekonomi-UI. Jakarta.

7. Huotari, K. \& Hamari, J., 2012. Defining gamification. Proceeding of the 16th International Academic MindTrek Conference on - MindTrek '12, 17. https://doi.org/10.1145/2393132.2393137

8. Harris, Scott dan Kevin O'Gorman. 2014. Mastering Gamification - Customer Engagement in 30 days. Cetakan Pertama. Impackt Publishing. UK.

9. Stevens, P., Pooley, R. (2000), Using UML Software Engineering with Objects and Components, Addison-Wesley.

10. Zichermann, G. (2011), Getting 3 Fs in Gamification. [Online], retrieved June 6, 2013 from http://www.gamification. co/2012/01/19/getting-three-fs-in-gamification/

11. Csikszentmihalyi, M. (1990), Flow: The Psychology of Optimal Experience. Harpers Perennial, NewYok.

12. Werbach, K. \& Hunter, D. (2012), For the Win: How Game Thinking Can Revolutionize Your Business, Wharton Digital Press. 